\title{
Management of Cattle Dung and Novel Bioelectricity Generation Using Microbial Fuel Cells: An Ingenious Experimental Approach
}

\author{
Gagandeep Kaur, ${ }^{1}$ Yadwinder Singh Brar, ${ }^{1}$ Jaspreet Kaur, ${ }^{2}$ Akhil Gupta ${ }^{(D)}{ }^{1}$ \\ Kamal Kant Sharma, ${ }^{3}$ Jasgurpreet Singh Chohan $\left(\mathbb{D},{ }^{4}\right.$ Raman Kumar (iD, ${ }^{4}$ \\ Shubham Sharma $\mathbb{D}^{5}{ }^{5}$ Somnath Chattopadhyaya, ${ }^{6}$ Shashi Prakash Dwivedi, ${ }^{7}$ \\ Alibek Issakhov, ${ }^{8}$ and Nima Khalilpoor (iD) ${ }^{9}$
}

\author{
${ }^{1}$ Electrical Engineering Department, I. K. Gujral Punjab Technical University Jalandhar, Kapurthala 144603, Punjab, India \\ ${ }^{2}$ Electronics and Communication Engineering Department, Beant College of Engineering \& Technology, \\ Gurdaspur, Punjab, India \\ ${ }^{3}$ Electrical Engineering Department, Chandigarh University, Mohali 140413, Punjab, India \\ ${ }^{4}$ Department of Mechanical Engineering, Chandigarh University, Gharuan, Mohali, Punjab 140413, India \\ ${ }^{5}$ Department of Mechanical Engineering, I. K. Gujral Punjab Technical University, Main Campus-Kapurthala, Jalandhar, \\ Punjab 144603, India \\ ${ }^{6}$ Department of Mechanical Engineering, Indian Institute Technology (Indian School of Mines), Dhanbad, Jharkhand, India \\ ${ }^{7}$ G. L. Bajaj Institute of Technology \& Management, Greater Noida, Gautam Buddha Nagar, U. P. 201310, India \\ ${ }^{8}$ Faculty of Mechanics and Mathematics, Department of Mathematical and Computer Modelling, \\ Al-Farabi Kazakh National University, Almaty, Kazakhstan \\ ${ }^{9}$ Department of Energy Engineering, Graduate School of the Environment and Energy, Science and Research Branch, \\ Islamic Azad University, Tehran, Iran
}

Correspondence should be addressed to Nima Khalilpoor; nimakhalilpoor@gmail.com

Received 11 February 2021; Revised 21 March 2021; Accepted 8 October 2021; Published 31 October 2021

Academic Editor: Sébastien Déon

Copyright (c) 2021 Gagandeep Kaur et al. This is an open access article distributed under the Creative Commons Attribution License, which permits unrestricted use, distribution, and reproduction in any medium, provided the original work is properly cited.

Microbial fuel cells (MFCs) are the rising modern equipment for the generation of bioelectricity from organic matters. In this study, MFCs in two formats are assembled and concurrently operated for a 30-day period in a batch mode manner. Natural biowaste cattle dung slurry with mediators is used as a substrate persistently for the enhancement of electron transfer rate and additionally for the augmentation of required electrical parameters. Under similar conditions, the MFC setups are experimented with a variety of anode-cathode material combinations, namely carbon-carbon, copper-carbon, and zinc-carbon. The performance of these MFCs during the testing period is evaluated independently and compared by plotting polarization data generated by them. It is revealed that maximum current and power densities are achieved from all these MFCs and the best attained values are $1858 \mathrm{~mA} / \mathrm{m}^{2}$ and $1465 \mathrm{~mW} / \mathrm{m}^{2}$, respectively, for the novel single-chamber zinc-carbon electrode MFC. The corresponding findings present that the MFC with zinc-carbon electrodes has the better power density than other MFCs. Being conductive and higher standard potential metal electrodes have improved the capability to act in place of carbon family electrodes for MFC-based power applications. Although the MFC power generation is low, but modifications in configurations, electrodes, microbe-rich biowaste, mediators, and power management may enhance the power output to a significant level for commercialization of this technology. The unique feature of this research is to explore the pertinent use of conductive metal electrodes to enhance the power generation capability of MFCs through biowaste as an alternative power source for small applications. The novelty of this research is presented through usage of conductive metal electrodes for the performance analysis of MFCs. 


\section{Introduction}

Globally, the consumption of energy has augmented exponentially during the first decade of the 21st century and is continuing to do so. The dire need of the present scenario is to meet the ever-increasing energy demand and identify more and all feasible sources of energy. Nonrenewable sources are presently the most conspicuous means for catering to the world's energy consumption pattern in which the key role is played by fossil fuels [1]. It is common knowledge that fossil fuels are likely to be exhausted and indiscriminate exploitation of fossil fuels have posed a threat to the biological life on the planet via their secondary effects such as global warming and environmental pollution [2]. The need for alternatives to fossil fuels have encouraged researchers to seek alternative sources for power, which can be harnessed by utilizing modern tools of technology developed in recent years and in a better manner than in the past $[3,4]$. As a consequence of these efforts, one of the recently proposed alternatives is energy derived from fuel cells utilizing presently wasted biomasses. A fuel cell is an electrochemical engine that converts the existing energy of chemical bonds into electricity [5]. Being a green source of energy, this option seems attractive as the energy obtained thereof is both renewable and environmentally friendly. Fuel cells utilizing biological material are biological fuel cells, capable of directly transforming chemical energy to electrical energy by the way of electrochemical reactions [6]. Biological fuel cells are classified in two types: MFCs and EFCs. If biological fuel cells are using biomass to act as a biocatalyst for bioelectricity production, then it may be named as biomass cells.

MFCs are devices that use bacterial community as the catalyst for oxidation of organic or inorganic matters, thus leading to generate current [7]. The MFC unit has an anodic and a cathodic chamber, and the two are separated by a semipermeable membrane known as PEM. In the anodic chamber, the microflora results in generation of protons and electrons via oxidation of organic matter in an anaerobic environment, generating carbon dioxide and other compounds as final products. The movement of electrons generated in the process is facilitated via an external circuit, whereby protons are transmitted to the cathodic chamber via PEM. In the cathode chamber, protons and electrons react along with parallel reduction of oxygen to water. A biopotential developed between the bacterial metabolic and these conditions led to generate bioelectricity in MFCs [1]. Anaerobic conditions are necessary in the anodic chamber as oxygen will hamper electricity production, consequently a pragmatic arrangement have to assemble for bacterial separation from oxygen $[1,6-8]$. The chemical reactions taking place in the anode and cathode chambers with organic matter substrates and water are as follows:

$$
\begin{aligned}
& \mathrm{C}_{6} \mathrm{H}_{12} \mathrm{O}_{6}+6 \mathrm{H}_{2} \mathrm{O}=6 \mathrm{CO}_{2}+24 \mathrm{H}+24 \mathrm{e}^{-} \text {(anode chamber) } \\
& 24 \mathrm{e}^{-}+24 \mathrm{H}+6 \mathrm{O}_{2}=12 \mathrm{H}_{2} \mathrm{O} \text { (cathode chamber) } \\
& \mathrm{C}_{6} \mathrm{H}_{12} \mathrm{O}_{6}+6 \mathrm{H}_{2} \mathrm{O}+6 \mathrm{O}_{2}=6 \mathrm{CO}_{2}+12 \mathrm{H}_{2} \mathrm{O} \text { (MFC reaction) }
\end{aligned}
$$

MFC performance mainly depends on several important factors such as system configuration, nature of organic matter, bacterial species, electrode material and surface area, type of catholyte, operating conditions, rate of oxidation in the anodic chamber, electron shuttle from the anodic chamber to surface of anode, way of supply and amount of consumption, and permeability of PEM $[1,9]$. An MFC is an incredible technology with the capability to use a wide range of substrates, configurations, and materials with bacteria to get bioelectricity generation despite the fact that power levels are low. This is a preferred method for longer sustainable power applications. The glimpse of pros and cons of MFCs is shown in Table 1 and is an indicative of motivation for research.

Recent literature reviews evidence that power generation from microalgae biomass using MFCs is a recent significant way to enhancing its efficiency and achieving large-scale applications. The mixed microalgae in the single chamber with normal carbon electrodes achieved the maximum power of $76 \mathrm{~mW} / \mathrm{m}^{2}$, and again with mixed microalgae in a single chamber with gold-graphite electrodes achieved the maximum power density of $10 \mathrm{~W} / \mathrm{m}^{2}$ [10]. A comprehensive review on MFCs and plant MFCs being renewable energy sources has presented that it has been developed for many applications such as waste water treatment, biosensors, biofuels, and contaminated sediments [11]. An overview on the development and modification of anode materials for MFCs presents that MFCs follow the electrochemical approach for natural conversion of organic waste to energy. The conductivity, surface area, porosity, biocompatibility, stability, availability, and cost of material are prime factors for selection of anodes. Except carbon anodes, metal or metal-oxide anodes such as zinc, nickel, copper, gold, and iron, are also making a place for energy generation [12]. A comprehensive review on the MFC technology presented various processes, utilization, and recent developments in usage of various carbon electrodes with different substrates and bacterial species [13]. The bioelectricity generation from different biomass feed with analysis of vital parameters presented the experimental results that showed the presence of percentage organic matter in cow dung along with drain water was 0.85 and same generated $230 \mathrm{mV}$ of voltage [14]. This has demonstrated the scope for bioremediation and manufacturing of anionic and polymeric bioemulsifiers with promising dispersing characteristics. A new biomolecule was utilized and prepared from UCP 1601 with emulsifying behaviour [15]. Another study [16] reported the use of pomegranate peel that acts as bioadsorbents for wastewater treatment. The potential of agriculture biomass for adsorption properties has been verified and approved by various studies. Similarly, an investigation for the treatment of synthetic textile using anaerobic and combined anaerobic-aerobic reactor systems has been carried out. Removal of toxic matter with minimal environmental degradation has been demonstrated [17].

Mostly, a review of advanced research referred in [10-17] indicates a research gap that no comprehensive performance analysis of MFCs with cattle dung as a substrate for a wide range management of cattle waste and the effect of different 
TABLE 1: Pros and cons of MFCs.

\begin{tabular}{lc}
\hline Pros & Cons \\
\hline Direct generation of power & Low power output \\
Sustainable alternate source of energy & Slow rate of growth of microbial population \\
Environment friendly & Toxicity of material \\
Effective conversion of energy & High material cost \\
Low cost for small applications & High cost for large-scale applications \\
Possibility of several MFC designs & High internal resistance \\
\hline
\end{tabular}

electrodes like popularly used carbon and novel metals on the performance of MFCs have been done. In addition, the scientometric analysis has been conducted based on keywords generated through the Scopus database. Thus, the studies conducted related to MFCs and bioelectricity in past research have raised many issues related to the performance of MFCs, and this present study tries to contribute through this paper. Figure 1 shows the scientometric chart generated through the VOSviewer analytical tool, which indicates that limited research has been carried out on manures acquired from animal waste. This analysis indicates that cattle dung must be considered for energy generation through MFCs.

Thus, the present study purposefully aims to investigate the performance parameters of cattle dung-based MFCs with carbon and metal electrodes. The aim behind this study has opened up the way for novelty of this research as an experimental work for the performance analysis of technical parameters of cattle dung-based MFCs in different designs with commonly used carbon and metal electrodes.

\section{Materials and Methods}

2.1. Material for MFC Assemblies. The different types, sizes, and structures of anode and cathode materials for MFC assemblies have been used by researchers to maximize the power generation and columbic efficiencies of MFCs [18-23]. In this research, for MFC assemblies, materials for anode electrodes with surface areas of $42.4 \mathrm{~cm}^{2}$ are carbon, copper, and zinc and for cathode electrodes only carbon is used. Before using for assemblies, the electrodes are washed with $1 \% \mathrm{HgCl}_{2}$ and stored in $0.1 \mathrm{M} \mathrm{HCl}$ and soaked in deionized water for a period of 24 hours. For physical separation of anode and cathode chambers in MFC designs, the separator materials are classified in terms of their qualities of filtration as resulting ion-exchange membranes, salt bridge, and size selective separators [7, 24]. The labgrade chemicals/materials as PEM are used for assemblies and supplied by Merck. The popularly used DuPont USA Nafion (117) membrane is used as per the size of MFC reactor. The substrates for these assemblies are cattle dung available in abundant as waste, rich in microorganism and nutrients. The substrate is prepared in the lab by adding distilled water to fresh cattle dung, making it as slurry in a ratio of $1: 4$ to act as the anolyte without any pretreatment and distilled water or natural air as the catholyte to make $\mathrm{O}_{2}$ as an electron acceptor. Quantitative analysis evidences that different quantities of cellulose, hemicelluloses, and lignin are found in dung with a small number of other extractives $[6,25]$. Fibre content of lignocellulose dung, such as

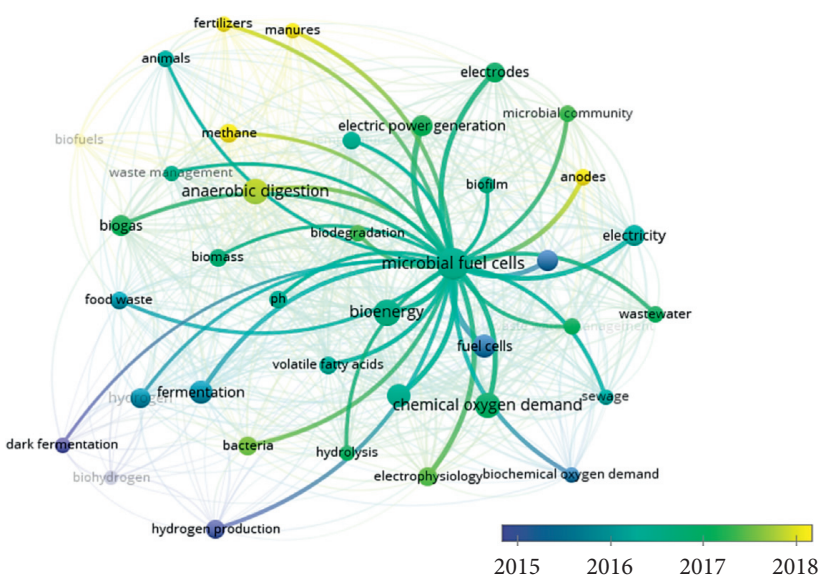

FIgURE 1: Scientometric chart analysis.

cellulose, hemicellulose, and lignin, has been found by the analysis of ADF, NDF, and ADL using the reflux apparatus and by following standard method of testing. Total lignocellulose material has been estimated by NDF and ADF is used to estimate the content of lignin and cellulose, which are the prime criteria for energy conversion technique. In the present work, the random samples of fresh cattle dung are collected by trained persons from local dairy farms of one region, Punjab, by following the standard method of sample collection and tested at SSNIBE, Punjab, and the results of fibre analysis are presented in Table 2.

2.2. Microbial Community Analysis. Cattle dung is an ideal candidate as energy a feedstock because of easily degradable high organic matter. Since long, manure has been extensively appreciated as a fertilizer but harmful due to considerable water and air pollution. Cattle dung is an alternative option for generation of electricity through MFCs and simultaneously maintains fertilizer value. This study explores the treatment of dung in terms of examining the presence of microbial species to activate the generation of bioelectricity process in MFCs. It is well known that microorganisms such as Bacillus and Pseudomonas act as electrifying bacteria in organic matters, which further help in microbial degradation of pollutants [26]. The results of microbial analysis are presented in Table 3. Furthermore, the scientometric analysis has been performed to highlight the use of manure as a fertilizer and energy source in India. Figure 2 shows the keyword relationship between cattle dung and its implementation as a manure and fertilizer for 
TABLE 2: Fibre analysis of fresh cattle dung.

Lignocellulose (\%)

Hemicellulose (\%)

Lignin (\%)

Extractives/volatiles (\%)

Ash (\%)

Lignin-to-cellulose ratio

agriculture purpose. In India, cattle dung is considered an excellent alternative to chemical-based fertilizers as India is a country with large rural population. The presence of chemicals such as phosphorus, carbon, and other minerals improves the fertility of soil with minimum cost. The chart in Figure 2(b) depicts the utilization of cattle dung as an energy source, which is highlighted as reported in recent studies. In rural areas, cattle dung is still used as an energy source due to its availability in abundance. Biogas plants are installed to extract biogas, which is used for cooking and industrial applications.

2.3. MFC Configurations. An inexpensive and widely used configuration is the $\mathrm{H}$-shaped double-chamber MFC consisting of two chambers separated by a membrane or salt bridge. These $\mathrm{H}$-shaped chambers are acceptable for examining power production with different materials, microbes, mediators, etc. However, the produced power density is limited by high internal resistance and subsequent scaling is cumbersome in such configurations [7]. Power density and system internal resistance are the key characteristics dependent on properties such as the surface area of the cathode, anode, or separator and distance kept between electrodes [27]. To conquer this complexity, a virtual alternative that offers cost and operational saving is a singlechamber MFC $[6,12]$. In the single chamber, the anode electrode is kept in anaerobic conditions in an anodic compartment and the cathode electrode is exposed to air called single-chamber air cathode MFC. Higher currents and voltages can be attained by series and parallel stacking of MFCs $[6,8,9,16]$. However, the key issue is the long-term impact of voltage reversal in stacked MFCs, which need further research for improved voltage production [9]. In this study, novel single-chamber MFC assemblies are fabricated and examined with standard test procedures for feasibility of MFCs as a power source. DCMFC assemblies are experimented with formation of three individual cells: DCMFC1, DCMFC2, and DCMFC3. In these double-chamber MFCs, the common materials used are two plastic containers as the anode and cathode chamber, Nafion membrane of suitable dimensions, and cattle dug slurry of $700 \mathrm{ml}$ in the anode chamber and $700 \mathrm{ml}$ distilled water in the cathode chamber with potassium permanganate of $300 \mu \mathrm{mol} / \mathrm{l}$ as the mediator in the cathode chamber. Carbon-carbon electrodes in DCMFC1, copper-carbon electrodes in DCMFC2, and zinccarbon electrodes in DCMFC3, all are of same area and shape, act as anode and cathode electrodes, respectively, and the basic design prepared and implemented in this study is shown in Figure 3(a). To analyze the performance of SCMFCs, SCMFC assemblies named as SCMFC4, SCMFC5,
TABLE 3: Isolated microbial analysis.

\begin{tabular}{lc}
\hline Isolate & Identified bacteria \\
\hline B1 & Bacillus subtilis \\
B2 & Escherichia coli \\
B3 & Streptococcus species \\
B4 & Pseudomonas aeruginosa \\
B5 & Clostridium species \\
B6 & Peptostreptococcus species \\
B7 & Bacillus cereus \\
B8 & Klebsiella species \\
B9 & Bacteroides species \\
\hline
\end{tabular}

and SCMFC6 are experimented with formation of three independent cells. Each SCMFC consists of a single chamber containing an anode electrode without any aerated cathode chamber. The anode compartment of the plastic container is loaded with dung slurry of $700 \mathrm{ml}$ with methylene blue of $300 \mu \mathrm{mol} / 1$ as the mediator coupled to the porous cathode exposed directly to air. The anode compartment and cathode are provided with sample port, wire point inputs, and ports for electrode wires. The cathode electrode is pasted through Nafion membrane of suitable dimensions with a $20-30 \%$ of electrode area is embedded in the membrane and the rest is exposed to air outside of the anode compartment. Carboncarbon electrodes in SCMFC4, copper-carbon electrodes in SCMFC5, and zinc-carbon electrodes in SCMFC6, all are of same area, are used as anode and cathode electrodes, respectively. The basic schematic of SCMFC assembly designed and implemented in this study is shown in Figure 3(b). The six experimental setups of DCMFC and SCMFC are operated continuously in batch mode for a period of 30 days under ambient conditions.

2.4. Calculation of Electrical Parameters. The maximum voltage theoretically attained by MFCs with organic substrate and carbon family electrodes is of the order of $1.1 \mathrm{~V}$. The oxygen reduction reaction at the cathode does not provide the theoretical potential of $+0.84 \mathrm{~V}$ because of the impact of activation losses on potential. Moreover, the ohmic and activation losses are more dominant as resistances are lowered and current increases. Due to these losses, the measured MFC voltage is considerably lower. These voltages are recorded using a multimeter. The commonly achieved maximum working voltage for MFCs is $0.3-0.7 \mathrm{~V}$. The peak voltage attained in MFCs is always the OCV. Current and power are calculated as per standards followed by research works. Primary parameters like "current" and "power density" were calculated by dividing current and power, respectively, by the projected surface area of electrodes. Polarization data are obtained by changing external resistances from $25 \Omega$ to $1000 \Omega$ [7, 8, 27-29].

\section{Results and Discussion}

3.1. Characterization of Cattle Dung. For the utilization of cattle dung as a substrate, the characterization of dung has been done by fibre analysis and microbial analysis. The 


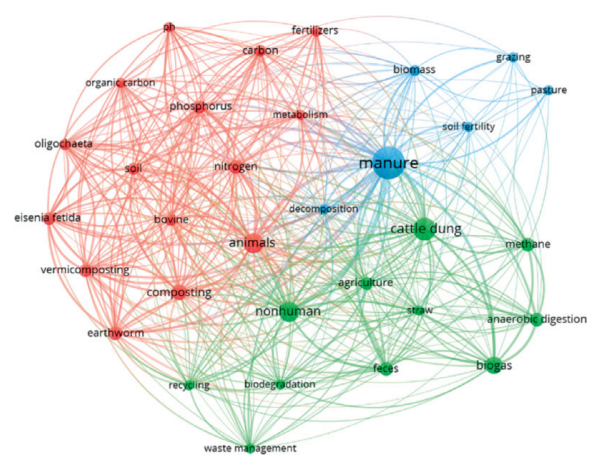

(a)

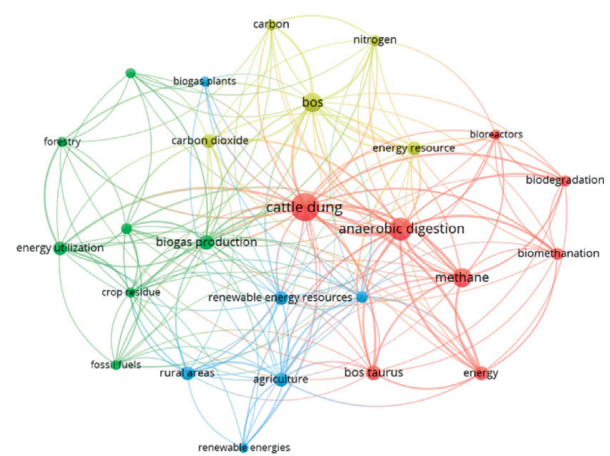

(b)

Figure 2: Scientometric analysis of utilization of cattle dung as (a) manure and (b) energy source.

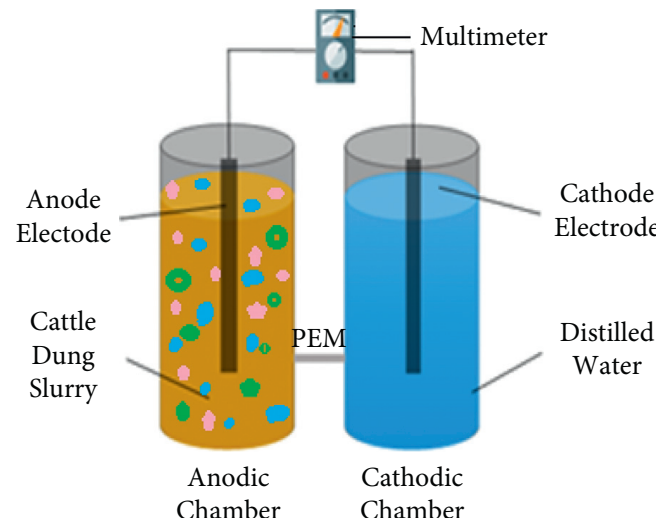

(a)

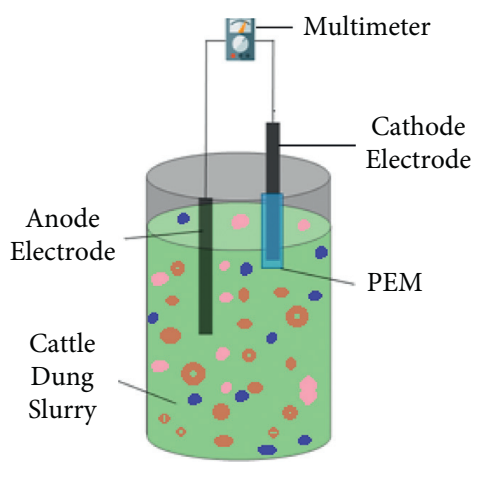

(b)

Figure 3: (a) Double-chamber MFC. (b) Single-chamber MFC.

results of fibre and microbial analyses are presented in Tables 2 and 3, respectively.

The results of fibre analysis in Table 2 reveal the ligninto-cellulose ratio along with other polymers, namely cellulose, hemicelluloses, lignin, extractives or volatiles, and ash content. Higher cellulose represents good potential for biomethanation. Cattle dung has a medium range of (24\%) cellulose and moderately good for the process. Hemicellulose of $14 \%$ for dung is most appropriate for anaerobic digestion (AD). Higher the lignin content lower is the digestibility as it is difficult to degrade in anaerobic conditions. Cattle dung has (4\%), very less value of lignin and suitable for the AD process. In case of lignocellulose biomass, the lignin-to-cellulose ratio is normally used to define the degree of digestibility of biomass. The lignin-to-cellulose ratio for dung was 0.167 with extractives of $44 \%$ and ash $14 \%$. All above results for the characterization of biomass are comparable with the results of $[9,21,30,31]$. The results conclude that dung has immense properties to act as a sustainable renewable energy source for electrical power generation.

Similarly, the microbial population of specific species is necessary for decomposition of organic matters, which further activates the electron flow process and generation of bioelectricity. Bacterial isolates are classified on the basis of their features in different forms of species. The isolation and identification of bacterial count are the most important steps for dung analysis. Isolation of microbes in dung has shown the prominent presence of nine bacterial species (Table 3 ), which play a vital role in the anaerobic process and also have been previously shown by researchers $[10,32,33]$. To enhance the power generating capabilities of MFCs, identification of power-developing bacteria is mandatory. Identification and viable count always helped in addition of particular types of bacteria as mediators for the augmentation of power density.

\subsection{Performance of Double-Chamber MFCs. DCMFCs are} continuously operated in batch mode for a period of 30 days, and the OCV of all cells are measured daily and the maximum achieved voltages are shown in Table 4. This relatively high voltage can be attributed to a high standard electrode potential and conductivity of the anode electrode with the same substrate for each cell [34-41]. With the stabilization of cells' output voltages, the performance of each cell is evaluated at a ten-day interval by plotting polarization curves. The polarization curves are plotted in Figure 4 after making measurements by utilizing multiple external resistances with values ranging from OCV $1000 \Omega$, $500 \Omega, 250 \Omega, 100 \Omega, 50 \Omega$, to $25 \Omega$. The voltages across 
TABLE 4: Electrical parameters of DCMFCs and SCMFCs.

\begin{tabular}{|c|c|c|c|c|c|c|}
\hline Cell number & DCMFC1 & DCMFC2 & DCMFC3 & SCMFC4 & SCMFC5 & SCMFC6 \\
\hline $\mathrm{OCV}(\mathrm{mV})$ & 946 & 915 & 1184 & 1098 & 1078 & 1292 \\
\hline Current (mA) & 4.73 & 4.58 & 5.68 & 6.81 & 6.68 & 7.88 \\
\hline Current density $\left(\mathrm{mA} / \mathrm{m}^{2}\right)$ & 1116 & 1080 & 1340 & 1606 & 1575 & 1858 \\
\hline Power $(\mathrm{mW})$ & 2.24 & 2.10 & 3.23 & 4.64 & 4.46 & 6.21 \\
\hline Power density $\left(\mathrm{mW} / \mathrm{m}^{2}\right)$ & 528 & 495 & 762 & 1094 & 1052 & 1465 \\
\hline
\end{tabular}

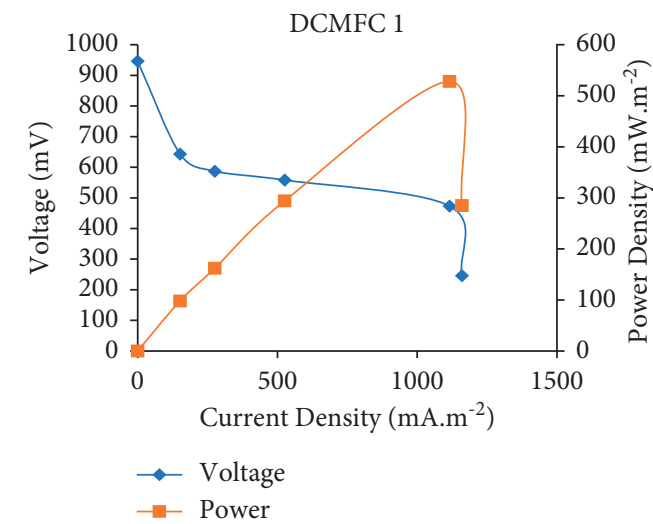

(a)

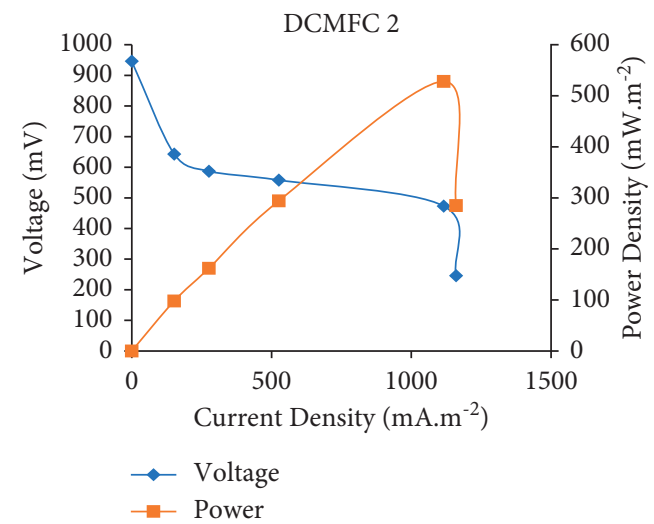

(b)

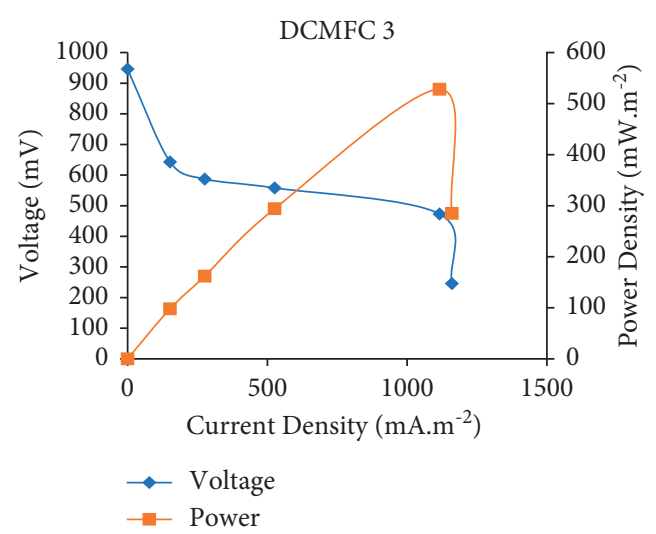

(c)

Figure 4: Polarization curves of (a) DCMFC1, (b) DCMFC2, and (c) DCMFC3.

these resistors are recorded every 3 hours in order to allow the bacterial cultures to produce sufficient current at lower voltages, which in addition provide enough time for biofilm to adapt changes in resistances. The polarization curves of cells evidence that the voltage drop is $50 \%$ as current increased to $4.73 \mathrm{~mA}$ at $100 \Omega$ in order to maximize power production in case of DCMFC1. Similarly, in DCMFC2, the drop in voltage is $49 \%$ as current increased to $4.58 \mathrm{~mA}$ at $100 \Omega$, and in DCMFC3, the drop in voltage is $48 \%$ as current increased to $5.68 \mathrm{~mA}$ at $100 \Omega$. The maximum generated power densities and current densities for cells DCMFC1, DCMFC2, and DCMFC 3 are $528 \mathrm{~mW} / \mathrm{m}^{2}$ and $1116 \mathrm{~mA} / \mathrm{m}^{2}, 495 \mathrm{~mW} / \mathrm{m}^{2}$ and $1080 \mathrm{~mA} / \mathrm{m}^{2}$, and $762 \mathrm{~mW} /$ $\mathrm{m}^{2}$ and $1340 \mathrm{~mA} / \mathrm{m}^{2}$, respectively, and are shown in Table 4.
3.3. Performance of Single-Chamber MFCs. The performance of SCMFCs differs considerably from DCMFCs due to the different MFC reactor design. The experimental conditions and materials used for SCMFCs are similar to DCMFCs, such as electrode material, substrates, and membranes [42-45]. Like DCMFCs, SCMFCs are continuously operated for 30 days in batch mode. The maximum OCV achieved in all three SCMFCs is shown in Table 4. The performance of these cells is also evaluated by the polarization curves as shown in Figure 5 at maximum voltages using adjustable external resistances of the same range as in DCMFCs to determine current and power densities. The maximum generated power and current densities for cells SCMFC4, SCMFC5, and SCMFC6 are $1094 \mathrm{~mW} / \mathrm{m}^{2}$ and $1606 \mathrm{~mA} / \mathrm{m}^{2}$, $1052 \mathrm{~mW} / \mathrm{m}^{2}$ and $1575 \mathrm{~mA} / \mathrm{m}^{2}$, and $1465 \mathrm{~mW} / \mathrm{m}^{2}$ and 


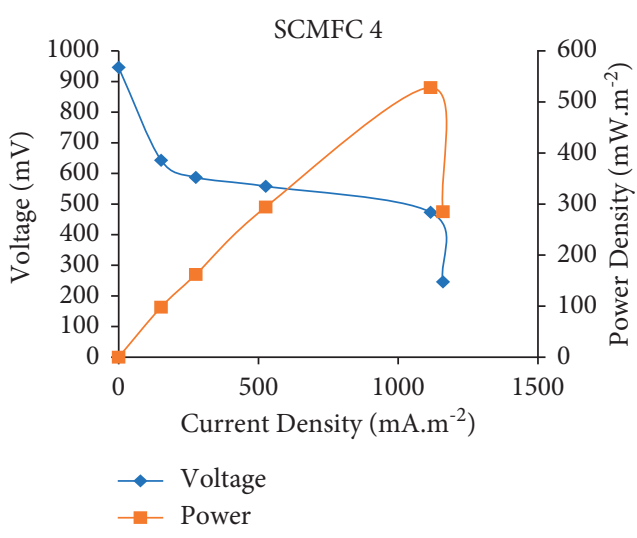

(a)

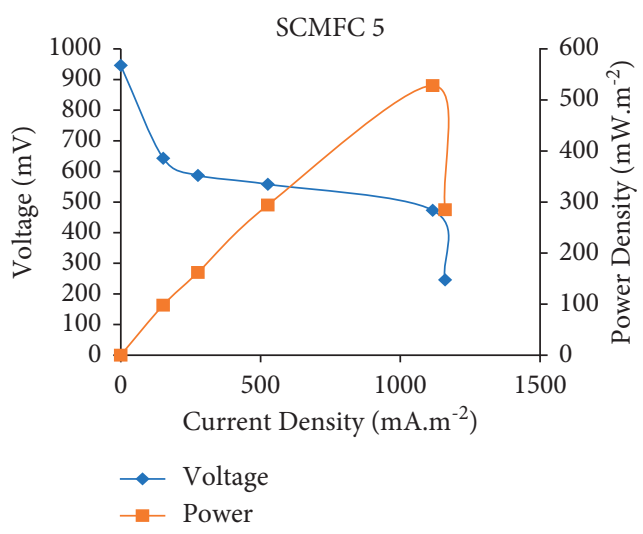

(b)

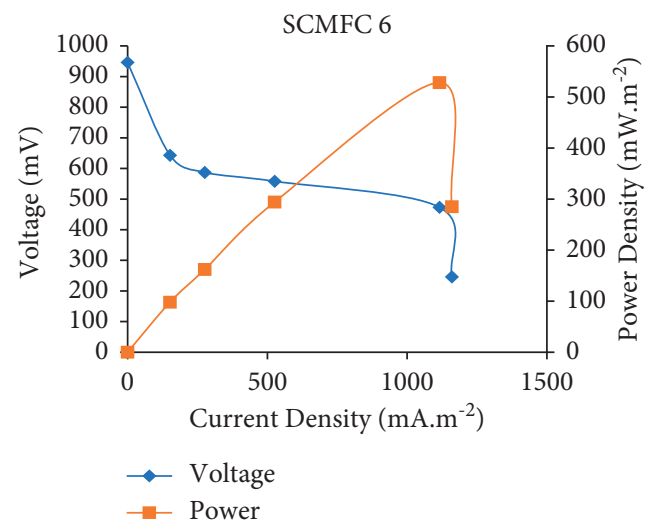

(c)

FIgUre 5: Polarization curves of (a) SCMFC4, (b) SCMFC5, and (c) SCMFC6.

$1858 \mathrm{~mA} / \mathrm{m}^{2}$, respectively. Performance parameters of other electrical quantities are similarly recorded and presented in Table 4.

The comparison of power densities and current densities of DCMFCs and SCMFCs operated in this study have shown that SCMFC6 performed best among all cells with the maximum power density of $1465 \mathrm{~mW} / \mathrm{m}^{2}$ and current density of $1858 \mathrm{~mA} / \mathrm{m}^{2}$. Results in references [7, 32] have amply defended those performances of MFCs and cannot be compared with our results because of simultaneous variations of so many parameters such as configuration, electrode type, surface area, substrate, electron transfer, microbial population, atmospheric conditions, and anaerobic conditions. Though there are few research works on biomass wastes-based MFCs with carbon and metal electrodes, their findings are compared with this study results and presented in Table 5.

Broadly, the results of present study are much better than those of others in terms of power densities, but this approximate comparative chart has neglected many significant factors such as electron transfer rate, microbial population, and size and shape of electrodes. Results of the studies indicate that cattle dung when used as a substrate in an MFC results in a full-grown and well-formed biofilm due to microbial action, which is the primary parameter for consistent electrical performance. The higher power and current densities of metal electrode MFCs can perform better in rich organic matters.

\section{Challenges in Implementation of MFC Technology}

There are immense challenges in implementation of this technology, and multiple issues have been faced by many researchers who worked on various configurations, but till date no configuration has been commercialized. MFC performance especially power and energy output are not only dependent on technical parameters rather it mainly associates with the process of biochemical conversion. Low power density and low current are the major barriers in commercialization of this technology. Cells polarity, voltage overshoots, and voltage reversals are the main issues of low MFC performance. Measurement of such low values requires lots of precision and accuracy of high technology instruments. There are also technical hitches in comparing the MFC performances on corresponding basis. As an agricultural country like India, it is indeed challenging to use such technology since organic matter seems abundant; however, contamination of organic matter is widespread ubiquitous. 
TABle 5: Comparison analysis of various studies.

\begin{tabular}{|c|c|c|c|c|}
\hline Substrate & Anode & Cathode & Power density & References \\
\hline $\begin{array}{l}\text { Glucose with Pseudomonas } \\
\text { aeruginosa bacteria }\end{array}$ & Carbon/graphite & Carbon/graphite & $\begin{array}{c}2096.5 \pm 11.8 \mu \mathrm{W} / \\
\mathrm{m}^{2}\end{array}$ & [34] \\
\hline Glucose with Escherichia coli & Carbon/graphite & Carbon/graphite & $1606 \mathrm{~mW} / \mathrm{m}^{2}$ & [35] \\
\hline Glucose with Escherichia coli & Carbon/graphite & Carbon/graphite & $2420 \mathrm{~mW} / \mathrm{m}^{2}$ & {$[36]$} \\
\hline Algae strain & Carbon & Copper sheet & $19151 \mathrm{~mW} / \mathrm{m}^{2}$ & [37] \\
\hline 一 & $\begin{array}{c}\text { Alumina and nickel } \\
\text { nanoparticles }\end{array}$ & $\begin{array}{c}\text { Polymer alumina and nickel } \\
\text { nanoparticles }\end{array}$ & $1270+30 \mathrm{~mW} / \mathrm{m}^{2}$ & [38] \\
\hline Biowaste from environment & Carbon/graphite & Carbon/graphite & $396.7 \mathrm{~mW} / \mathrm{m}^{2}$ & [39] \\
\hline Livestock waste & Carbon/graphite & Carbon/graphite & $122 \mathrm{~mW} / \mathrm{m}^{2}$ & {$[40]$} \\
\hline Mixed microalgae & Carbon & Carbon & $76 \mathrm{~mW} / \mathrm{m}^{2}$ & {$[10]$} \\
\hline Mixed microalgae & Gold & Graphite & $10 \mathrm{~W} / \mathrm{m}^{2}$ & {$[10]$} \\
\hline Cattle dung with B1-B9 bacteria & Zinc & Carbon & $1465 \mathrm{~mW} / \mathrm{m}^{2}$ & $\begin{array}{c}\text { Present } \\
\text { study }\end{array}$ \\
\hline
\end{tabular}

\section{Conclusions}

DCMFCs with conventional H-design and SCMFCs with novel designs are fabricated and operated successfully in batch mode for a period of 30 days under similar physical conditions. The objectives of these MFC assemblies are to analyze the significant electrical performance parameters as power densities and current densities using cattle dung substrate and carbon and metal electrodes. Usage of metal electrodes is rarely preferred in MFC configurations with a perception of metal corrosion and difficulty in accumulation of microbes on plane surfaces. The main findings of this study are the successful operation of metal electrode MFCs with the rough surface of novel metal electrodes for both configurations and SCMFC6 having zinc-carbon electrodes achieved the maximum power density. The maximum OCV achieved for SCMFC6 is $1292 \mathrm{mV}$, and with standard tests the maximum obtained current is $8 \mathrm{~mA}$, the maximum power of $6.21 \mathrm{~mW}$, and the maximum power density is $1465 \mathrm{~mW} / \mathrm{m}^{2}$ at $100 \Omega$. The MFC is a prominent technology for bioelectricity generation and offers prospects for utilization of various organic wastes with novel metal electrodes. This study has more scope for further research as this technology is still at the laboratory level and needs bundles of diverse approaches before commercialization. A number of organic wastes, carbon family materials, and especially metals are open for research to enhance the power outputs of cells. New designs of cells, simulation and modelling of cells, and quality of power can be the advance areas of research. Handling of trouble shootings for MFC assembly and operation are the thrust areas, which require comprehensive research.

\section{Abbreviations}

MFC: $\quad$ Microbial fuel cell

EFCs: Enzymatic fuel cells

PEM: $\quad$ Proton-exchange membrane

$\mathrm{HgCl}_{2}$ : Mercury chloride

HCl: Hydrogen chloride

ADF: $\quad$ Acid detergent fibre

NDF: $\quad$ Neutral detergent fibre

ADL: Acid detergent lignin
$\mathrm{O}_{2}: \quad$ Dioxygen

DCMFC: Double-chamber MFC

SCMFC: Single-chamber MFC

OCV: Open circuit voltage.

\section{Data Availability}

The data presented in this study are available on request from the corresponding author.

\section{Additional Points}

(i) (ii) Management of waste cattle dung through bioelectricity generation has been demonstrated. Bioelectricity generation using carbon and metal electrodes in MFC is highlighted

(iii) Polarization data have been plotted for testing the performance of cells independently

(iv) Achievement of high current and power densities with single-chamber MFC has been reported

\section{Conflicts of Interest}

The authors declare that there are no conflicts of interest with anyone.

\section{Authors' Contributions}

Conceptualization of the study was developed by Gagandeep Kaur, Yadwinder Singh Brar, and Raman Kumar. Methodology of the study was designed by Jaspreet Kaur, Akhil Gupta, and Shubham Sharma. Study investigations were carried out by Gagandeep Kaur, Kamal Kant Sharma, Jasgurpreet Singh Chohan, and Shubham Sharma. Original draft preparation was done by Gagandeep Kaur, Shubham Sharma, S Chattopadhyaya, SP Dwivedi, Alibek Issakhov, and Nima Khalilpoor.

\section{Acknowledgments}

The work is based on the doctorate thesis of the first author, who wants to affectionately express gratitude to her mentors. The authors are deeply indebted to Ms. Harbhajan Kaur and 
Mr. Gobinder Singh, retired officers of PSPCL of Punjab province, India, for their invaluable contributions in the experimental work. The authors also than I. K. Gujral Punjab Technical University Jalandhar, India, for all technical and academic support.

\section{References}

[1] M. Rahimnejad, A. Adhami, S. Darvari, A. Zirepour, and S.-E. Oh, "Microbial fuel cell as new technology for bioelectricity generation: a review," Alexandria Engineering Journal, vol. 54, no. 3, pp. 745-756, 2015.

[2] D. Lovely, "Microbial fuel cells: novel microbial physiologies and engineering approaches," Current Opinion in Biotechnology, vol. 17, pp. 327-332, 2006.

[3] D. P. B. T. B. Strik, H. Terlouw, H. V. M. Hamelers, and C. J. N. Buisman, "Renewable sustainable biocatalyzed electricity production in a photosynthetic algal microbial fuel cell (PAMFC)," Applied Microbiology and Biotechnology, vol. 81, no. 4, pp. 659-668, 2008.

[4] A. E. Franks and K. P. Nevin, "Microbial fuel cells, a current review," Energies, vol. 3, no. 5, pp. 899-919, 2010.

[5] B. C. H. Steele and A. Heinzel, "Materials for fuel-cell technologies," Nature, vol. 414, no. 6861, pp. 345-352, 2001.

[6] G. S. Gupta, "Microbial fuel cell technology: a review on electricity generation," Journal of Cell \& Tissue Research, vol. 11, no. 1, pp. 2631-2654, 2011.

[7] B. E. Logan, B. Hamelers, R. Rozendal et al., "Microbial fuel cells: methodology and technology," Environmental Science \& Technology, vol. 40, no. 17, pp. 5181-5192, 2006.

[8] J. Choi and Y. Ahn, "Continuous electricity generation in stacked air cathode microbial fuel cell treating domestic wastewater," Journal of Environmental Management, vol. 130, pp. 146-152, 2013.

[9] M. Rahimnejad, A. A. Ghoreyshi, G. D. Najafpour, H. Younesi, and M. Shakeri, "A novel microbial fuel cell stack for continuous production of clean energy," International Journal of Hydrogen Energy, vol. 37, no. 7, pp. 5992-6000, 2012.

[10] M. E. Elshobary, H. M. Zabed, J. Yun, G. Zhang, and X. Qi, "Recent insights into microalgae-assisted microbial fuel cells for generating sustainable bioelectricity," International Journal of Hydrogen Energy, vol. 46, no. 4, pp. 3135-3159, 2021.

[11] W. Apollon, A. Isabel luna, S. Kumar Kamaraj et al., "Progress and recent trends in photosynthetic assisted microbial fuel cells: a review," Biomass and Bioenergy, vol. 148, pp. 1-14, Article ID 10828, 2021.

[12] A. A. Yaqoob, M. N. M. Ibrahim, and S. R. Couto, "Development and modification of materials to build cost-effective anodes for microbial fuel cells (MFCs): an overview," Biochemical Engineering Journal, vol. 164, pp. 1-14, Article ID 10779, 2020.

[13] G. Palanisamy, H.-Y. Jung, T. Sadhasivam, M. D. Kurkuri, S. C. Kim, and S.-H. Roh, "A comprehensive review on microbial fuel cell technologies: processes, utilization, and advanced developments in electrodes and membranes," Journal of Cleaner Production, vol. 221, pp. 598-621, 2019.

[14] G. harshita, A. sahoo, and R. Sethy, "Bioelectricity generation from different biomass feed at anode chamber and to study process parameters in microbial fuel cells," Biocatalysis and Agricultural Biotechnology, vol. 20, pp. 1-4, Article ID 101191, 2019.
[15] I. B. Nogueira, D. Montero Rodríguez, and F. Rosildeide, "Bioconversion of agroindustrial waste in the production of bioemulsifier by Stenotrophomonas maltophilia UCP 1601 and application in bioremediation process," International Journal of Chemical Engineering, vol. 2020, Article ID 9434059, 9 pages, 2020.

[16] S. Ben-Ali, "Application of raw and modified pomegranate peel for wastewater treatment: a literature overview and analysis," International Journal of Chemical Engineering, vol. 2021, Article ID 8840907, 19 pages, 2021.

[17] T. M. Kathawala, K. V. Gayathri, and P. Senthil Kumar, "A performance comparison of anaerobic and an integrated anaerobic-aerobic biological reactor system for the effective treatment of textile wastewater," International Journal of Chemical Engineering, vol. 2021, Article ID 8894332, 15 pages, 2021.

[18] U. Schröder, "Anodic electron transfer mechanisms in microbial fuel cells and their energy efficiency," Physical Chemistry Chemical Physics, vol. 9, no. 21, pp. 2619-2629, 2007.

[19] P. Aelterman, K. Rabaey, H. T. Pham, N. Boon, and W. Verstraete, "Continuous electricity generation at high voltages and currents using stacked microbial fuel cells," Environmental Science \& Technology, vol. 40, no. 10, pp. 3388-3394, 2006.

[20] F. J. Hernández-Fernández, A. Pérez de los Ríos, M. J. SalarGarcía et al., "Recent progress and perspectives in microbial fuel cells for bioenergy generation and wastewater treatment," Fuel Processing Technology, vol. 138, pp. 284-297, 2015.

[21] A. D. Tharali, N. Sain, and W. J. Osborne, "Microbial fuel cells in bioelectricity production," Frontiers in Life Science, vol. 9, no. 4, pp. 252-266, 2016.

[22] A. Baudler, I. Schmidt, M. Langner, A. grenier, and U. Schroder, "Does it have to be carbon? Metal anodes in microbial fuel cells and related bio-electrochemical systems," Energy and Environmental Science, vol. 8, p. 2039, 2015.

[23] N. Haque, D. Cho, and S. Kwon, "Characteristics of electricity production by metallic and nonmetallic anodes immersed in mud sediment using sediment microbial fuel cell," IOP Conference Series: Materials Science and Engineering, vol. 88, 2015 7th International Conference on Cooling \& Heating Technologies (ICCHT 2014), Article ID 012072.

[24] W.-W. Li, G.-P. Sheng, X.-W. Liu, and H.-Q. Yu, "Recent advances in the separators for microbial fuel cells," Bioresource Technology, vol. 102, no. 1, pp. 244-252, 2011.

[25] P. Mckendry, "Energy production from biomass (part 1): overview of biomass," Bioresource Technology, vol. 83, no. 1, pp. 37-46, 2002.

[26] G. Zhao, F. Ma, L. Wei, H. Chua, C.-C. Chang, and X.-J. Zhang, "Electricity generation from cattle dung using microbial fuel cell technology during anaerobic acidogenesis and the development of microbial populations," Waste Management, vol. 32, no. 9, pp. 1651-1658, 2012.

[27] A. N. Ghadge and M. M. Ghangrekar, "Performance of low cost scalable air-cathode microbial fuel cell made from clayware separator using multiple electrodes," Bioresource Technology, vol. 182, pp. 373-377, 2015.

[28] J. Winfield, L. D. Chambers, J. Rossiter, J. Greenman, and I. Ieropoulos, "Towards disposable microbial fuel cells: natural rubber glove membranes," International Journal of Hydrogen Energy, vol. 39, no. 36, pp. 21803-21810, 2014.

[29] V. J. Watson and B. E. Logan, "Analysis of polarization methods for elimination of power overshoot in microbial fuel cells," Electrochemistry Communications, vol. 13, no. 1, pp. 54-56, 2011. 
[30] P. C. Roy, A. Datta, and N. Chakraborty, "Assessment of cow dung as a supplementary fuel in a downdraft biomass gasifier," Renewable Energy, vol. 35, no. 2, pp. 379-386, 2010.

[31] K. Inoue, T. Ito, Y. Kawano et al., "Electricity generation from cattle manure slurry by cassette-electrode microbial fuel cells," Journal of Bioscience and Bioengineering, vol. 116, no. 5, pp. 610-615, 2013.

[32] K. Rabaey, S. T. Read, P. Clauwaert et al., "Cathodic oxygen reduction catalyzed by bacteria in microbial fuel cells," The ISME Journal, vol. 2, no. 5, pp. 519-527, 2008.

[33] Y. Zuo, D. Xing, J. M. Rehan, and B. E. Logan, "Isolation of the exoelectrogenic bacterium Ochrobactrum anthropi YZ-1 by using a U-tube microbial fuel cell," Applied and Environmental Microbiology, vol. 74, pp. 3130-3137.

[34] J. Jayapriya and V. Ramamurthy, "Use of non-native phenazines to improve the performance of Pseudomonas aeruginosa MTCC 2474 catalysed fuel cells," Bioresource Technology, vol. 124, pp. 23-28, 2012.

[35] X. Chen, D. Cui, X. Wang, X. Wang, and W. Li, "Porous carbon with defined pore size as anode of microbial fuel cell," Biosensors and Bioelectronics, vol. 69, pp. 135-41, 2015.

[36] Y. Tao, Q. Liu, J. Chen et al., "Hierarchically three-dimensional nanofiber based textile with high conductivity and biocompatibility as a microbial fuel cell anode," Environmental Science and Technology, vol. 50, no. 95, p. 7889, 2016.

[37] Q. Hou, H. Pei, W. Hu, L. Jiang, and Z. Yu, "Mutual facilitations of food waste treatment, microbial fuel cell bioelectricity generation and Chlorella vulgaris lipid production," Bioresource Technology, vol. 203, pp. 50-55, 2016.

[38] S. Singh, A. Modi, and N. Verma, "Enhanced power generation using a novel polymer-coated nanoparticles dispersedcarbon micro-nanofibers-based aircathode in a membraneless single chamber microbial fuel cell," International Journal of Hydrogen Energy, vol. 41, pp. 1237-1247, 2016.

[39] M. Sindhuja, S. Harinipriya, A. C. Bala, and A. K. Ray, "Environmentally available biowastes as substrate in microbial fuel cell for efficient chromium reduction," Journal of Hazardous Materials, vol. 355, pp. 197-205, 2018.

[40] M. F. Lai, C. W. Lou, and J. H. Lin, "Improve 3D electrode materials performance on electricity generation from livestock wastewater in microbial fuel cell," International Journal of Hydrogen Energy, vol. 43, pp. 11520-11529, 2018.

[41] M. A. Jokar, M. H. Ahmadi, M. Sharifpur, J. P. Meyer, F. Pourfayaz, and T. Ming, "Thermodynamic evaluation and multi-objective optimization of molten carbonate fuel cellsupercritical CO 2 Brayton cycle hybrid system," Energy Conversion and Management, vol. 153, pp. 538-556, 2017.

[42] A. Khatibi, F. Razi Astaraei, and M. H. Ahmadi, "Generation and combination of the solar cells: a current model review," Energy Science \& Engineering, vol. 7, no. 2, pp. 305-322, 2019.

[43] M. Sadeghzadeh, B. Ghorbani, M. H. Ahmadi, and S. Sharma, "A solar-driven plant to produce power, cooling, freshwater, and hot water for an industrial complex," Energy Report, vol. 7, pp. 5344-5358, 2021.

[44] K. K. Sharma, A. Gupta, G. Kaur et al., "Power quality and transient analysis for a utility-tied interfaced distributed hybrid wind-hydro controls renewable energy generation system using generic and multiband power system stabilizers," Energy Report, vol. 7, pp. 5034-5044, 2021.

[45] K. K. Sharma, A. Gupta, R. Kumar et al., "Economic evaluation of a hybrid renewable energy system (HRES) using hybrid optimization model for electric renewable (HOMER) software-a case study of rural India," International Journal of Low-Carbon Technologies, vol. 16, no. 3, pp. 1-8, 2021. 